Archive for

Organic Chemistry

Arkivoc 2019, part iii, 53-66

\title{
Synthesis and DNA binding of 6-(alkylamino)indolo[1,2-b][2,7]naphthyridine-5,12-quinones
}

\author{
Deborah A. Davis, ${ }^{a}$ Michael Cory, ${ }^{b}$ Terri A. Fairley, ${ }^{b}$ and Gordon W. Gribble*a
}

${ }^{a}$ Department of Chemistry, Dartmouth College, Hanover, NH 03755, USA

${ }^{b}$ Division of Organic Chemistry, Burroughs Wellcome Company, Research Triangle Park, North Carolina 27709

Email: ggribble@dartmouth.edu

This paper is to celebrate George A. Kraus for his many outstanding contributions to organic chemistry

Received 12-17-2018

Accepted 01-17-2019

Published on line 01-27-2019

\section{Abstract}

We describe the synthesis of eight novel putative mono- and bis-DNA intercalators from a common precursor, 6-bromoindolo[1,2-b][2,7]naphthyridine-5,12-dione. Of these new indoloquinones, our data indicate that two are most likely DNA mono-intercalators, but weaker than ethidium bromide, and two others are DNA bis-intercalators. Our indoloquinones are inactive against mammalian topoisomerase II.<smiles></smiles><smiles>CC(F)(F)C1CC(N)CC1N</smiles><smiles></smiles>

Keywords: Indole, DNA intercalation, amination, 6-bromoindolo[1,2- $b][2,7]$ naphthyridine-5,12-dione, indoloquinone 


\section{Introduction}

The antitumor activity and DNA affinity of amino-substituted quinones is well established, ${ }^{1-4}$ and several drugs in this category have seen utility in the cancer clinic; for example, mitomycin (1), ${ }^{5,6}$ ametantrone (2), ${ }^{7}$ mitoxantrone (3), ${ }^{8,9}$ pixantrone (4), ${ }^{10-12}$ and WEHI-150 (5) ${ }^{13,14}$ (Figure 1).<smiles>COC12C(COC(N)=O)C3=C(C(=O)C(N)=C(N)C3=O)N1CC1NC12</smiles>

Mitomycin (1)<smiles>NCCNc1ccc(NCCN)c2c1C(=O)c1ccncc1C2=O</smiles>

Pixantrone (4)<smiles>[R]c1ccc([R])c2c1C(=O)c1c(NCCNCCO)ccc(NCCN(C)CCO)c1C2=O</smiles>

Ametantrone (2, $\mathrm{R}=\mathrm{H})$ Mitoxantrone $(3, \mathrm{R}=\mathrm{OH})$<smiles>NCCNCCNc1ccc(NCCNCCN)c2c1C(=O)c1c(O)ccc(O)c1C2=O</smiles>

WEHI-150 (5)

\section{Figure 1}

We have previously synthesized and utilized the indolo[1,2-b][2,7]naphthyridine-5,12-dione (6) ring system to forge several members of the $6 \mathrm{H}$-pyrido[4,3-b]carbazole family of antitumor alkaloids, including ellipticine (7), 9-methoxyellipticine (8), olivacine (9), 13-oxoellipticine (10), 7,8,9,10-tetrafluoroellipticine (11), and ellipticine quinone $(\mathbf{1 2})^{15-20}$ (Figure 2). A variation of our method allowed for the synthesis of $10 \mathrm{H}$ pyrido[2,3-b]carbazoles $(\mathbf{1 3})^{21}$ and 6,11-disubstituted-benzo[b]carbazoles (14). ${ }^{22}$ The shape similarity of quinone (6) with that of ellipticine quinone (12) and calothrixin B (15), both of which display antitumor activity, $^{23-25}$ suggested that it would be fruitful to examine indoloquinone 6 and its amino-substituted derivatives for DNA binding, given the known enhancement of DNA binding and resulting biological activity imparted by the alkylamino side chains in antitumor quinones $\mathbf{2}-\mathbf{5}$. 
<smiles>O=C1c2ccncc2C(=O)n2c1cc1ccccc12</smiles>

6<smiles>Cc1c2cnccc2c(C=O)c2[nH]c3ccccc3c12</smiles>

10<smiles>Cc1c2ncccc2c(C)c2c1[nH]c1ccccc12</smiles>

13<smiles>[R]c1ccc2[nH]c3c(C)c4ccncc4c(C)c3c2c1</smiles>

7, $\mathrm{R}=\mathrm{H}$

8, $\mathrm{R}=\mathrm{OMe}$<smiles>Cc1c2cnccc2c(C)c2c1[nH]c1c(F)c(F)c(F)c(F)c12</smiles>

11<smiles>[R]c1c2ccccc2c([R])c2c1[nH]c1ccccc12</smiles>

14<smiles>Cc1nccc2c(C)c3[nH]c4ccccc4c3cc12</smiles>

9<smiles>O=C1c2ccncc2C(=O)c2c1[nH]c1ccccc21</smiles>

12<smiles>O=C1c2cnc3ccccc3c2C(=O)c2c1[nH]c1ccccc21</smiles>

15

\section{Figure 2}

Fatefully, during attempts to isomerize indoloquinone 6 to ellipticine quinone (12) with various nucleophiles, we discovered the propensity for 6 to undergo oxidative dimerization at C- 6 to give $16^{26}$ (Scheme 1).

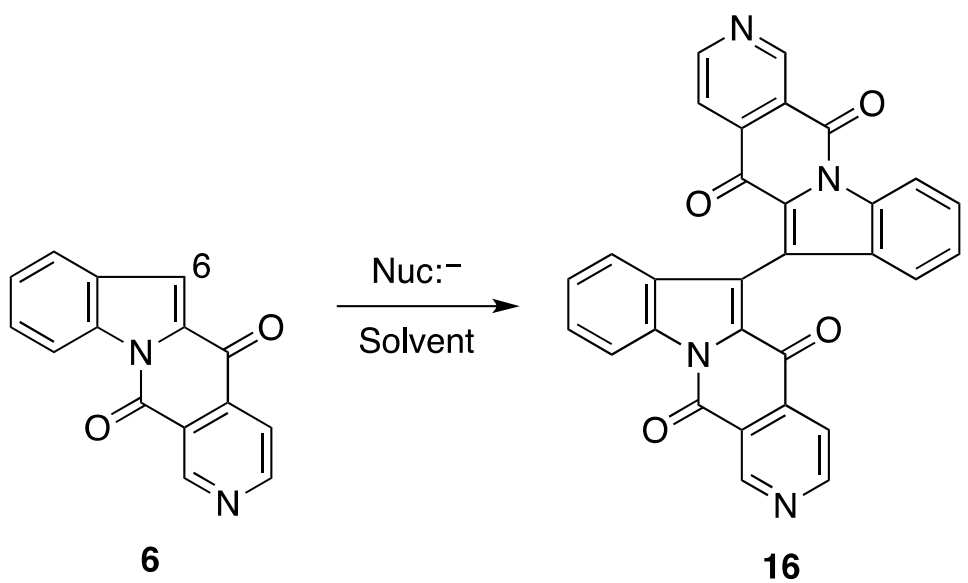

Nuc: $=\mathrm{NaCN}, \mathrm{KF}, \mathrm{NaCl}, \mathrm{Mg}(\mathrm{OMe})_{2}, \mathrm{NaSPh}$

Solvent $=\mathrm{THF}, \mathrm{DMF}$, DMSO, HMPA

\section{Scheme 1}


This observation fortuitously provided a convenient synthesis of the C- 6 alkylamino derivatives 17a-d and the bis-compounds 18a-d, which we describe herein. Furthermore, it was conceivable that compounds of type 17 (or 18) might irreversibly acylate DNA, given the tendency of $N$-acylindoles to undergo facile nucleophilic cleavage of the nitrogen-carbonyl bond ${ }^{27,28}$ (i.e., $17 \rightarrow 19$ ) (Figure 3).<smiles>Nc1c2n(c3ccccc13)C(=O)c1cnccc1C2=O</smiles>

17

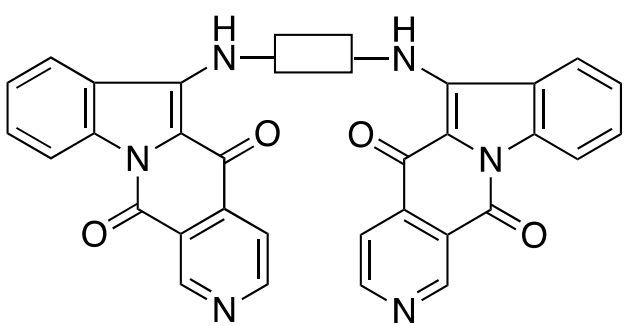

18<smiles>N#Cc1c(C(=O)c2ccncc2C(=O)O)[nH]c2ccccc12</smiles>

19

Figure 3

\section{Results and Discussion}

The targeted 6-(alkylamino)indolo[1,2-b][2,7]naphthyridine-5,12-diones (17a-d) and bis[6-aminoindolo[1,2b][2,7]naphthyridine-5,12-diones (18a-d) were synthesized from 1-(phenylsulfonyl)indole (20) as shown in Scheme 2. The synthesis of bromo indoloquinone (24) parallels our earlier synthesis of indoloquinone 6 . $^{15}$ The known 3-bromo-1-(phenylsulfonyl)indole (21), prepared quantitatively from 20 and bromine in methylene chloride, was treated with lithium di-isopropyl amide (LDA) at $-78{ }^{\circ} \mathrm{C}$, stirred at that temperature for one hour, and quenched with 3,4-pyridinedicarboxylic anhydride at $-100{ }^{\circ} \mathrm{C}$ to give the protected keto-acid (22) in $70 \%$ yield, after recrystallization from acetone to remove the minor regioisomer $(<2 \%)$. The phenylsulfonyl group was removed with $\mathrm{K}_{2} \mathrm{CO}_{3}$ in aqueous $\mathrm{MeOH}$-water (84\%), and the resulting deprotected keto acid (23) was cyclized to indoloquinone $\mathbf{2 4}$ in hot acetic anhydride (79\%).

As noted earlier, our motivation to explore the reaction of $\mathbf{2 4}$ with various amines, and examine their DNA affinity, was that the aminoanthraquinones ametantrone (2) and mitoxantrone (3) show strong DNA affinity and good antineoplastic activity in clinical trials. ${ }^{7}$ In actuality, treatment of $\mathbf{2 4}$ with an excess of dimethylamine (25\% aqueous solution) in THF at room temperature provided 5-dimethylaminoindolo[1,2b][2,7]naphthyridine-6,11-dione (17a) cleanly in high yield. Similarly, compounds $17 b$ and 17 c were synthesized by allowing solutions of $\mathbf{2 4}$ in THF to react with excess $N, N, N^{\prime}$-trimethylethylenediamine and 3diethylaminopropylamine, respectively. These reactions doubtlessly proceed by a typical nucleophilic addition-elimination mechanism. ${ }^{29}$ 
<smiles>CCCOS(=O)(=O)c1ccccc1</smiles>

1. LDA

2.<smiles>O=C1OC(=O)c2cnccc21</smiles><smiles>O=C(O)c1cnccc1C(=O)c1c(Br)c2ccccc2n1S(=O)(=O)O</smiles>

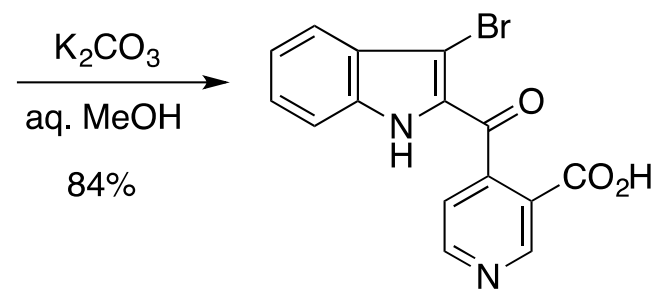

23<smiles>O=C(O)c1cncc2c(=O)c3ccc4c(c3)c(c(=O)c12)=C4Br</smiles>

24

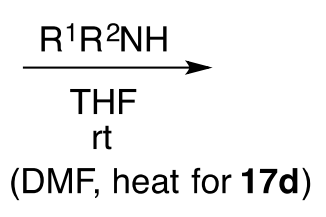<smiles>[R17]Nc1c2n(c3ccccc13)C(=O)c1cncc(C(=O)O)c1C2=O</smiles>

$17 a, R^{1}=R^{2}=\operatorname{Me}(82 \%)$

17b, $R^{1}=\mathrm{Me}, \mathrm{R}^{2}=\mathrm{CH}_{2} \mathrm{CH}_{2} \mathrm{NMe}_{2}$ (83\%)

17c, $R^{1}=\mathrm{H}, \mathrm{R}^{2}=\mathrm{CH}_{2} \mathrm{CH}_{2} \mathrm{CH}_{2} \mathrm{NEt}_{2}(66 \%)$

17d, $R^{1}=H, R^{2}=\operatorname{Me}(86 \%)$

\section{Scheme 2}

Interestingly, the reaction of $\mathbf{2 4}$ with hot dimethylformamide (DMF) produced 5-(methylamino)indolo[1,2b][2,7]naphthyridine-6,11-dione (17d) in $86 \%$ yield (Scheme 2 ). This peculiar reaction was discovered during attempts to displace bromide from 24 with 2-amino-2-methyl-1,3-propanediol ${ }^{30}$ in hot DMF, since milder conditions (THF, rt) were unproductive. To confirm that the methylamino group had come from DMF rather than via the decomposition of 2-amino-2-methyl-1,3-propanediol, a solution of 24 was heated in DMF for 24 hours; once, again, there was a clean conversion to $\mathbf{1 7 d}$. This phenomenon had been observed twenty years earlier by Lord and Peters, ${ }^{31}$ who observed that heating 1-chloroanthraquinone for 32 hours in DMF at reflux afforded a mixture of 1-dimethylaminoanthraquinone (25) and 1-methylaminoanthraquinone (26). Moreover, $\mathbf{2 5}$ was demethylated to $\mathbf{2 6}$ by additional heating in DMF for 73 hours. In contrast, 2-chloroanthraquinone gave only 2-dimethylaminoanthraquinone in refluxing DMF. These observations are wholly consistent with a demethylation mechanism involving assistance by the neighboring carbonyl group as shown for the formation of 17d from 24 (Scheme 3). 


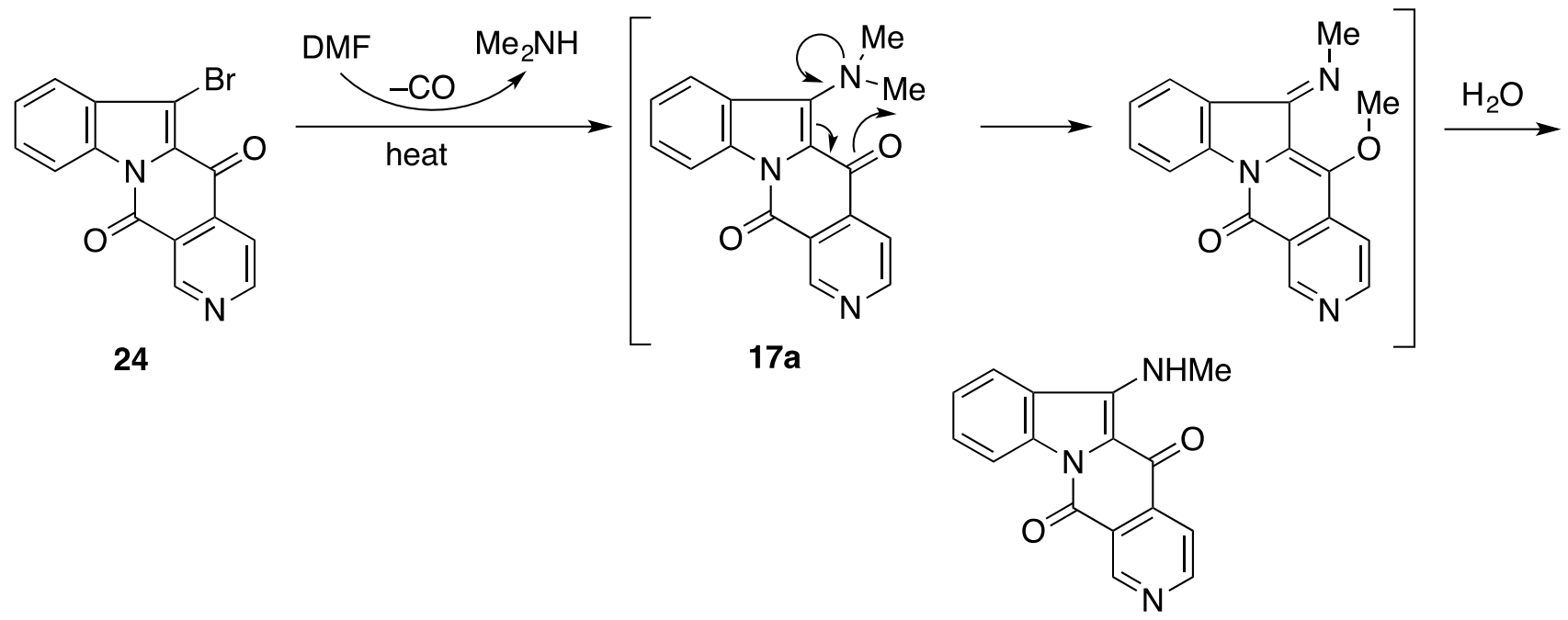

$17 d$<smiles></smiles>

25<smiles>CNc1cccc2c1C(=O)c1ccc(OC)cc1C2=O</smiles>

26

\section{Scheme 3}

Our motivation for preparing the bis-indoloquinones $18 a-d$ was to attain novel DNA bis-intercalators, and we were encouraged by the results from our previous studies with bis-acridines. ${ }^{32}$ Indeed, as we found with bis-acridines, adjustment of the length and flexibility of the diamino-linkage (tether) can dramatically alter the DNA-binding of these compounds. Therefore, we prepared bis-indoloquinones 18a-d using a method similar to the method used to synthesize compounds 17a (Scheme 4). The reactions were run in the presence of excess 24 so as to encourage the formation of the bis-indoloquinones. Nonetheless, some monoindoloquinones were still present in the reaction mixture after 24 hours of stirring at room temperature. 


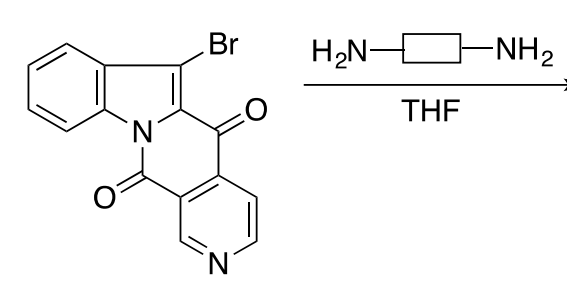

24<smiles></smiles>

$18 \mathrm{a}(48 \%)$<smiles></smiles>

18<smiles>C[R5](C)(C(C)(C)C)C(C)(C)C</smiles><smiles></smiles>

18d (23\%)

\section{Scheme 4}

The bromine in indoloquinone $\mathbf{2 4}$ is also susceptible to displacement by other nucleophiles (Scheme 5). Thus, treatment of $\mathbf{2 4}$ with $(n-\mathrm{Bu})_{4} \mathrm{NCl}$ in DMF gave an orange compound that was identical to an authentic sample of 6-chloroindolo[1,2-b][2,7]naphthyridine-5,12-dione (27). ${ }^{17}$ Similarly, 24 was treated with sodium methoxide in methanol to give a product identical to an authentic sample of 6-methoxyindolo[1,2b] [2,7]naphthyridine-5,12-dione (28). ${ }^{17}$ Such behavior is not unexpected as ß-haloenones are known to act as Michael acceptors for halogens, amines, alkoxides, and thiolates as well as carbon-based nucleophiles. ${ }^{33}$<smiles>O=C1c2cnccc2C(=O)n2c1c(Cl)c1ccccc12</smiles>

27

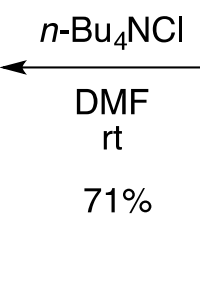

(1)<smiles>O=C1c2ccncc2C(=O)n2c1c(Br)c1ccccc12</smiles>

24<smiles></smiles>

28

\section{Scheme 5}


Our results of DNA affinity studies for $\mathbf{1 7 a - d}$ and $\mathbf{1 8 a - d}$ are summarized in Table 1 . The change in DNA melting, $\Delta T_{m}$, is the change in the thermal denaturation of DNA by a drug as a result of intercalation. ${ }^{34}$ From these results, it can be seen that compounds $\mathbf{1 7 b}$ and $\mathbf{1 7 c}$ are intercalators, although less effective when compared to a powerful intercalator such as the aminoacridine, quinacrine, which has a $\Delta T_{m}$ value of $24.9 .^{34}$ The other experiment was to determine the slope of the calf thymus viscometric titration. When a drug intercalates into DNA, the DNA helix lengthens. Thus, the line of concern here is the ratio of the increase in DNA contour length versus the drug/nucleotide ratio. ${ }^{34}$ Unfortunately, in further tests, neither of these compounds exhibited any activity against mammalian topoisomerase II, which are enzymes that cause doublestrand breaks in DNA, cause the DNA to unwind, and reseal the breaks. ${ }^{35}$ They are believed to be necessary for replication, since the helical winding of the DNA must be released to allow strand splitting in replication. Thus, it is currently believed that topoisomerase activity is crucial for useful anticancer activity. ${ }^{35}$ We find that 17a-d have no activity against mammalian topoisomerase II at a drug concentration of $100 \mu \mathrm{M}$.

Table 1. DNA affinity results for $17 a-d$ and 18 b,c

\begin{tabular}{|c|c|c|c|c|}
\hline Compound & CT DNA ${ }^{a}$ & $\begin{array}{l}\Delta T_{m}{ }^{\circ} \mathrm{C} \\
\text { Poly } A T^{b}\end{array}$ & Poly $\mathrm{GC}^{\mathrm{C}}$ & $\begin{array}{c}\text { Slope of Calf } \\
\text { Thymus viscosity titration }\end{array}$ \\
\hline $17 a$ & $0.3 \pm 0.2$ & & - & - \\
\hline $17 b$ & $8.7 \pm 0.05$ & $7.6 \pm 0.03$ & $3.7 \pm 0.65$ & $1.7 \pm 0.2$ \\
\hline $17 c$ & $8.5 \pm 0.02$ & $7.2 \pm 1.0$ & $4.5 \pm 1.8$ & $0.5 \pm 0.1$ \\
\hline $17 d$ & $0.56 \pm 0.41$ & & - & - \\
\hline $18 b$ & $21.7 \pm 7.4$ & & - & - \\
\hline $18 c$ & $7.8 \pm 6.8$ & $0.4 \pm 0.2$ & $-0.2 \pm 1.2$ & - \\
\hline 24 & $-0.4 \pm 0.2$ & & - & - \\
\hline $\begin{array}{l}\text { Ethidium } \\
\text { bromide }\end{array}$ & $11.9 \pm 1.1$ & $9.9 \pm 0.4$ & $5.3 \pm 0.7$ & - \\
\hline
\end{tabular}

\section{Conclusions}

We have synthesized eight novel indoloquinones, 17a-d and 18a-d for DNA binding studies. Of these, 17a and $\mathbf{1 7} \mathbf{d}$ do not bind to DNA as evidenced by the calf thymus DNA assay, suggesting that the pyridine ring system alone is insufficiently basic to become protonated in the presence of the polyphosphates of DNA. Moreover, as might be expected, the exocyclic amino group is rendered less basic by the C-5 carbonyl group (vinylogous amide). In contrast, our data indicate that $\mathbf{1 7 b}$ and $\mathbf{1 7 c}$ are probably mono-intercalators. These two quinones show a binding profile similar to other DNA intercalators, and they exhibit a GC preference. By comparison to ethidium bromide, these two compounds are somewhat weaker intercalators. In contrast, indoloquinones $\mathbf{1 8 b}$ and $\mathbf{1 8 c}$ are likely bis-intercalators, since the high CT for $\mathbf{1 8 b}$ and its biphasic nature suggests a double intercalator. The lesser DNA affinity of $\mathbf{1 8 c}$ is probably imparted by the less electronegative oxygen atoms in the tether. Our eight new compounds, 17a-d and 18a-d, will serve in future biological studies. 


\section{Experimental Section}

General. Melting points were determined on a Büchi 510 apparatus and are uncorrected. Infrared (IR) spectra were recorded on a Perkin-Elmer 599 spectrometer and are referenced to the $1601 \mathrm{~cm}^{-1}$ band of polystyrene. ${ }^{1} \mathrm{H}$ NMR $(300 \mathrm{MHz})$ and ${ }^{13} \mathrm{C}$ NMR $(75 \mathrm{MHz})$ were recorded on a Varian $\mathrm{XL}-300$ multinuclear Fourier transform spectrometer. Unitary resolution mass spectra (MS) were obtained on a Finnigan $4023 \mathrm{GC} / \mathrm{MS}$ system. High resolution mass spectra (HRMS) were recorded at the National Institutes of Health regional facility at the Massachusetts Institute of Technology. Ultraviolet (UV) spectra were recorded on a Hewlett Packard 8451A diode array spectrophotometer. Elemental analyses were performed by Atlantic Microlab Inc., Norcross, GA. Analytical thin-layer chromatography (TLC) was performed on precoated Silica Gel $60 F_{254}$ plates from EM Reagents. Visualization was accomplished with 254 and $365 \mathrm{~nm}$ UV light, iodine vapor, ceric ammonium sulfate spray ( $3 \%$ in $10 \%$ sulfuric acid) or "van Urk's reagent" spray ( $p$-dimethylaminobenzaldehyde in ethanolic sulfuric acid). Flash chromatography was performed with EM Reagents Silica Gel 60 (230-400 mesh). All reactions were performed under a static head of predried ( $\mathrm{CaSO}_{4}$ tower) nitrogen or argon in glassware that had been dried for at least $1 \mathrm{~h}$ at $135^{\circ} \mathrm{C}$. Benzenesulfonyl chloride and 3,4-pyridinedicarboxylic anhydride were distilled prior to use.

3-Bromo-1-(phenylsulfonyl)indole (21). To a stirred solution of 1-(phenylsulfonyl)indole ${ }^{36}$ (20) $(20.0 \mathrm{~g}, 77.8$ $\mathrm{mmol})$ in $\mathrm{CH}_{2} \mathrm{Cl}_{2}(125 \mathrm{~mL})$ was added bromine $(4.5 \mathrm{~mL}, 86 \mathrm{mmol})$ in $\mathrm{CH}_{2} \mathrm{Cl}_{2}(100 \mathrm{~mL})$ dropwise with stirring over $1 \mathrm{~h}$ at $\mathrm{rt}$, during which time $\mathrm{HBr}$ gas was evolved. After stirring for an additional $2 \mathrm{~h}$, saturated aqueous sodium thiosulfate solution $(250 \mathrm{~mL})$ was added and the biphasic mixture was stirred for 15 min. The layers were separated and the aqueous phase was extracted with $\mathrm{CH}_{2} \mathrm{Cl}_{2}(3 \times 50 \mathrm{~mL})$. The combined organic phase was washed with saturated aqueous $\mathrm{NaHCO}_{3}(2 \times 200 \mathrm{~mL}), \mathrm{H}_{2} \mathrm{O}(2 \times 200 \mathrm{~mL})$, brine $(200 \mathrm{~mL})$, dried $\left(\mathrm{Na}_{2} \mathrm{SO}_{4}\right)$, and concentrated in vacuo to yield $26.1 \mathrm{~g}(100 \%)$ of 21 as a white solid: $\mathrm{mp} 116-118{ }^{\circ} \mathrm{C}$ (lit., ${ }^{36} \mathrm{mp} 119-120{ }^{\circ} \mathrm{C}$ ); IR $\left(\mathrm{CHCl}_{3}\right)$ 1605, 1585, 1445, 1370, $1265 \mathrm{~cm}^{-1} ;{ }^{1} \mathrm{H}$ NMR $\left(\mathrm{CDCl}_{3}\right) \delta 7.15-8.15(\mathrm{~m}, 9 \mathrm{H}), 7.63(\mathrm{~s}, 1 \mathrm{H}) ;{ }^{13} \mathrm{C} \mathrm{NMR}$ $\left(\mathrm{CDCl}_{3}\right) \delta 137.7,134.2,134.1,129.4,129.3,126.8,125.8,124.7,123.9,120.0,113.5,99.8$.

3-Bromo-1-(phenylsulfonyl)indol-2-yl 3-carboxy-4-pyridyl ketone (22). To a solution of lithium diisopropylamide $(7.14 \mathrm{mmol})$ prepared from diisopropylamine $(1.00 \mathrm{~mL}, 7.14 \mathrm{mmol})$ and $\mathrm{n}$-butyllithium (1.22 $\mathrm{M}$ in hexane; $6.00 \mathrm{~mL}, 7.32 \mathrm{mmol})$ in dry THF $(40 \mathrm{~mL})$ under nitrogen at $-78{ }^{\circ} \mathrm{C}$ was added dropwise with stirring over $20 \mathrm{~min}$ a solution of $21(2.00 \mathrm{~g}, 5.95 \mathrm{mmol})$ in dry THF $(40 \mathrm{~mL})$. The mixture was stirred at $-78^{\circ} \mathrm{C}$ for $1 \mathrm{~h}$ then cooled to $-100{ }^{\circ} \mathrm{C}$ and treated as rapidly as possible with a solution of 3,4-pyridinedicarboxylic anhydride $(1.21 \mathrm{~g}, 8.11 \mathrm{mmol})$ in dry THF $(40 \mathrm{~mL})$ while maintaining efficient cooling and stirring. The mixture was allowed to warm slowly to rt with stirring over $18 \mathrm{~h}$ and then concentrated in vacuo. The resulting brown viscous oil was dissolved in $\mathrm{H}_{2} \mathrm{O}(250 \mathrm{~mL})$, cooled to $0{ }^{\circ} \mathrm{C}$, and slowly acidified with dilute $\mathrm{HCl}$. The resulting white precipitate was collected and dried in vacuo to give $2.53 \mathrm{~g}(88 \%)$ of crude product. Recrystallization from acetone yielded $2.01 \mathrm{~g}(70 \%)$ of 22 as a white powder: $\mathrm{mp} 234-236^{\circ} \mathrm{C}$ (dec); IR (KBr) 1715, 1675, 1450, 1365, 1260, 1175, 1070, 950, 860, 755, 735, $675 \mathrm{~cm}^{-1} ;{ }^{1} \mathrm{H}$ NMR (DMSO-d 6 ) $\delta 9.07(\mathrm{~s}, 1 \mathrm{H}), 8.97(\mathrm{~d}, 1 \mathrm{H}, J 4.8 \mathrm{~Hz}), 8.14$ $(\mathrm{d}, 1 \mathrm{H}, J 8.0 \mathrm{~Hz}), 7.98(\mathrm{~d}, 1 \mathrm{H}, J 8.0 \mathrm{~Hz}), 7.79-7.56(\mathrm{~m}, 7 \mathrm{H}), 7.50(\mathrm{~m}, 1 \mathrm{H}) ;{ }^{13} \mathrm{C}$ NMR (DMSO- $\left.d_{6}\right) \delta 184.7,166.5$, 153.0, 150.1, 144.9, 136.6, 136.4, 135.1, 133.5, 129.72, 129.67, 128.6, 127.1, 126.7, 125.7, 123.0, 121.8, 115.7, 110.9; $\mathrm{MS} \mathrm{m} / \mathrm{e} 486\left(\mathrm{M}^{+}+2\right), 484\left(\mathrm{M}^{+}\right), 328,326,264,220,164,141,77$ (100\%). Anal. Calcd for $\mathrm{C}_{21} \mathrm{H}_{13} \mathrm{BrN}_{2} \mathrm{O}_{5} \mathrm{~S}+$ $\mathrm{C}_{3} \mathrm{H}_{6} \mathrm{O}:$ C, 53.05; H, 3.52; Br, 14.71; N, 5.15; S, 5.90. Found: C, 52.86; H, 3.30; Br, 14.95; N, 5.25; S, 6.05.

3-Bromoindol-2-yl 3-Carboxy-4-pyridyl ketone (23). A magnetically stirred solution of keto acid 22 (1.00 g, $2.06 \mathrm{mmol}), \mathrm{K}_{2} \mathrm{CO}_{3}(1.2 \mathrm{~g}, 8.7 \mathrm{mmol}), \mathrm{H}_{2} \mathrm{O}(8 \mathrm{~mL})$, and $\mathrm{MeOH}(25 \mathrm{~mL})$ was heated under reflux for $45 \mathrm{~min}$. The mixture was cooled and the $\mathrm{MeOH}$ was removed in vacuo. The dark, oily residue was dissolved in $\mathrm{H}_{2} \mathrm{O}(100$ 
$\mathrm{mL}$ ), cooled to $0{ }^{\circ} \mathrm{C}$, and slowly acidified with dilute $\mathrm{HCl}$ with stirring. The yellow precipitate was collected by filtration and dried in vacuo to yield $0.49 \mathrm{~g}$ of 23. An additional $0.11 \mathrm{~g}$ of product was obtained by continuous extraction of the filtrate with $\mathrm{CH}_{2} \mathrm{Cl}_{2}$ to give a total of $0.60 \mathrm{~g}(84 \%)$ of $23: \mathrm{mp} 194-195{ }^{\circ} \mathrm{C}$; IR $(\mathrm{KBr}) 1710,1625$, $1505,1335,1260,1230,740 \mathrm{~cm}^{-1} ;{ }^{1} \mathrm{H}$ NMR (DMSO-d $)_{6} \delta 12.38(\mathrm{~s}, 1 \mathrm{H}), 9.22(\mathrm{~s}, 1 \mathrm{H}), 8.94(\mathrm{~d}, J 4.3 \mathrm{~Hz}, 1 \mathrm{H}), 7.61$ (d, J $4.3 \mathrm{~Hz}, 1 \mathrm{H}), 7.50(\mathrm{~m}, 2 \mathrm{H}), 7.41(\mathrm{~m}, 1 \mathrm{H}), 7.20(\mathrm{~m}, 1 \mathrm{H}) ;{ }^{13} \mathrm{C}$ NMR (DMSO- $\left.d_{6}\right) \delta 183.0,165.6,153.6,151.8$, $150.9,148.6,136.5,131.0,127.1,124.6,123.0,121.6,121.5,120.6,113.2$. A satisfactory analysis could not be obtained for this product so it was used directly in the next step.

6-Bromoindolo[1,2-b][2,7]naphthyridine-5,12-dione (24). A solution of 23 (0.60 g, $1.7 \mathrm{mmol})$ in $\mathrm{Ac}_{2} \mathrm{O}(25 \mathrm{~mL})$ was heated at $80^{\circ} \mathrm{C}$ for $4 \mathrm{~h}$. After cooling, most of the solvent was removed in vacuo, then $\mathrm{H}_{2} \mathrm{O}(50 \mathrm{~mL})$ and $\mathrm{CH}_{2} \mathrm{Cl}_{2}(50 \mathrm{~mL})$ were added. The layers were separated and the aqueous phase was further extracted with $\mathrm{CH}_{2} \mathrm{Cl}_{2}(2 \times 50 \mathrm{~mL})$. The combined organic phase was washed with $\mathrm{H}_{2} \mathrm{O}(2 \times 100 \mathrm{~mL})$ and brine $(100 \mathrm{~mL})$, dried $\left(\mathrm{Na}_{2} \mathrm{SO}_{4}\right)$, and adsorbed onto silica gel. Flash chromatography with EtOAc gave $0.45 \mathrm{~g}(79 \%)$ of 24 as a yellowgreen powder. Recrystallization from $\mathrm{CH}_{2} \mathrm{Cl}_{2}$ /hexane gave the analytical sample as fine yellow needles: $\mathrm{mp}$ 230-232 ${ }^{\circ} \mathrm{C}$ (dec); IR $\left(\mathrm{CHCl}_{3}\right)$ 2980, 2920, 1705, 1680, 1600, 1535, 1450, 1365, 1335, 1255, $1220 \mathrm{~cm}^{-1} ;{ }^{1} \mathrm{H} \mathrm{NMR}$ (DMSO-d $)_{6} \delta 9.35(\mathrm{~s}, 1 \mathrm{H}), 9.16(\mathrm{~d}, J 4.7 \mathrm{~Hz}, 1 \mathrm{H}), 8.54(\mathrm{~d}, J 7.9 \mathrm{~Hz}, 1 \mathrm{H}), 8.18(\mathrm{~d}, J 4.7 \mathrm{~Hz}, 1 \mathrm{H}), 7.75(\mathrm{~m}, 2 \mathrm{H}), 7.56$ $(\mathrm{m}, 1 \mathrm{H}) ;{ }^{13} \mathrm{C}$ NMR (DMSO- $\left.d_{6}\right) \delta 174.1,155.4,150.0,147.9,134.7,131.4,131.2,126.2,126.0,122.0,120.8$, 119.0, 118.3, 116.6, 108.7; MS m/e 328 ( $\left.\mathrm{M}^{+}+2,100 \%\right), 326\left(\mathrm{M}^{+}, 100 \%\right), 300,298,272,270,247,219,191,164$, 114. Anal. Calcd for $\mathrm{C}_{15} \mathrm{H}_{7} \mathrm{BrN}_{2} \mathrm{O}_{2}$ : C, 55.07; H, 2.16; $\mathrm{Br}, 24.43 ; \mathrm{N}, 8.56 ; \mathrm{O}, 9.78$. Found: $\mathrm{C}, 54.82 ; \mathrm{H}, 2.18 ; \mathrm{Br}$, 24.53; N, 8.49; O, 9.88.

6-Dimethylaminoindolo[1,2-b][2,7]naphthyridine-5,12-dione (17a). To a solution of 24 (100 mg, $0.31 \mathrm{mmol})$ in THF ( $25 \mathrm{~mL}$ ) was added excess $\mathrm{Me}_{2} \mathrm{NH}$ (25\% aqueous solution, $20 \mathrm{~mL}$ ). The mixture was stirred at $\mathrm{rt}$ for $6 \mathrm{~h}$, during which time the solution became bright orange. The solution was poured into EtOAc (100 $\mathrm{mL})$ and washed with saturated aqueous $\mathrm{NaHCO}_{3}(2 \times 50 \mathrm{~mL}), \mathrm{H}_{2} \mathrm{O}(2 \times 50 \mathrm{~mL})$ and brine $(50 \mathrm{~mL})$, then dried $\left(\mathrm{Na}_{2} \mathrm{SO}_{4}\right)$ and concentrated to give an orange powder. Recrystallization from THF-hexane gave $73 \mathrm{mg}(82 \%)$ of $17 \mathrm{a}$ as

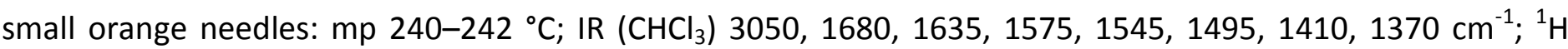
NMR $\left(\mathrm{CDCl}_{3}\right) \delta 9.62(\mathrm{~s}, 1 \mathrm{H}), 8.98(\mathrm{~d}, 1 \mathrm{H}, J 4.0 \mathrm{~Hz}), 8.86(\mathrm{~d}, 1 \mathrm{H}, J 9.6 \mathrm{~Hz}), 8.06(\mathrm{~d}, 1 \mathrm{H}, J 4.0 \mathrm{~Hz}), 8.00(\mathrm{~d}, 1 \mathrm{H}, J 9.6$ $\mathrm{Hz}), 7.62(\mathrm{~m}, 1 \mathrm{H}), 7.33(\mathrm{~m}, 1 \mathrm{H}), 3.49(\mathrm{~s}, 6 \mathrm{H})$; MS m/e $291\left(\mathrm{M}^{+}\right), 276(100 \%), 262,249,233,220,192,164,102$, 77, 44; Anal. Calcd for $\mathrm{C}_{17} \mathrm{H}_{13} \mathrm{~N}_{3} \mathrm{O}_{2}$ : C, 70.08; $\mathrm{H}, 4.50 ; \mathrm{N}, 14.42$. Found: $\mathrm{C}, 69.87 ; \mathrm{H}, 4.39 ; \mathrm{N}, 14.41$.

6-[N-[2-(Dimethylamino)ethyl]methylamino]indolo[1,2-b][2,7]naphthyridine-5,12-dione (17b). To a solution of $24(65 \mathrm{mg}, 0.20 \mathrm{mmol})$ in THF $(5 \mathrm{~mL})$ was added excess $\mathrm{N}, \mathrm{N}, \mathrm{N}^{\prime}$-trimethylethylenediamine $(0.10 \mathrm{~mL}, 0.78$ $\mathrm{mmol})$. The mixture was refluxed for $1 \mathrm{~h}$, during which time the solution became dark orange. The solution was cooled and poured into EtOAc $(50 \mathrm{~mL})$ and washed with saturated aqueous $\mathrm{NaHCO}_{3}(2 \times 25 \mathrm{~mL}), \mathrm{H}_{2} \mathrm{O}(2 \times$ $25 \mathrm{~mL})$ and brine $(25 \mathrm{~mL})$, then dried $\left(\mathrm{Na}_{2} \mathrm{SO}_{4}\right)$ and concentrated to give a red powder. Recrystallization from $\mathrm{CH}_{2} \mathrm{Cl}_{2}$-hexane gave $57 \mathrm{mg}$ (83\%) of $17 \mathrm{~b}$ as short red needles: $\mathrm{mp} 129-131{ }^{\circ} \mathrm{C}$; IR $\left(\mathrm{CHCl}_{3}\right) 2950,2800,1675$, $1630,1570,1530,1495,1460,1410,1370,1330 \mathrm{~cm}^{-1} ;{ }^{1} \mathrm{H} \mathrm{NMR}\left(\mathrm{CDCl}_{3}\right) \delta 9.62(\mathrm{~s}, 1 \mathrm{H}), 8.99(\mathrm{~d}, 1 \mathrm{H}, J 5.1 \mathrm{~Hz}), 8.87$ $(\mathrm{d}, 1 \mathrm{H}, J 8.1 \mathrm{~Hz}), 8.08(\mathrm{~d}, 1 \mathrm{H}, J 5.1 \mathrm{~Hz}), 8.01(\mathrm{~d}, 1 \mathrm{H}, J 8.1 \mathrm{~Hz}), 7.64(\mathrm{~m}, 1 \mathrm{H}), 7.35(\mathrm{~m}, 1 \mathrm{H}), 3.95(\mathrm{t}, 2 \mathrm{H}), 3.50(\mathrm{~s}$, $3 \mathrm{H}), 2.68(\mathrm{t}, 2 \mathrm{H}), 2.22(\mathrm{~s}, 6 \mathrm{H}) ;{ }^{13} \mathrm{C} \mathrm{NMR}\left(\mathrm{CDCl}_{3}\right) \delta 174.7,168.0,157.9,153.9,151.0,150.9,141.4,137.5,131.6$, $124.9,124.5,124.3,124.0,118.5,118.3,57.6,54.8,45.7,43.1 ; \mathrm{MS} m / e 348\left(\mathrm{M}^{+}\right), 303,290,277,262,248,233$, 80, 58 (100\%); Anal. Calcd for $\mathrm{C}_{20} \mathrm{H}_{20} \mathrm{~N}_{4} \mathrm{O}_{2}+0.5 \mathrm{H}_{2} \mathrm{O}:$ C, 67.21; H, 5.92; N, 15.67. Found: C, 67.78; $\mathrm{H}, 5.76 ; \mathrm{N}$, 15.23.

6-[3-(Diethylamino)propylylamino]indolo[1,2-b][2,7]naphthyridine-5,12-dione (17c). To a solution of 24 (56 $\mathrm{mg}, 0.17 \mathrm{mmol})$ in THF $(5 \mathrm{~mL})$ was added excess 3-diethylaminopropylamine $(0.10 \mathrm{~mL}, 0.63 \mathrm{mmol})$. The mixture was refluxed for $1 \mathrm{~h}$, during which time the solution became dark orange. The solution was cooled and poured into EtOAc $(50 \mathrm{~mL})$ and washed with saturated aqueous $\mathrm{NaHCO}_{3}(2 \times 25 \mathrm{~mL}), \mathrm{H}_{2} \mathrm{O}(2 \times 25 \mathrm{~mL})$ and brine 
$(25 \mathrm{~mL})$, and then dried $\left(\mathrm{Na}_{2} \mathrm{SO}_{4}\right)$ and concentrated to give an orange semi-solid. Recrystallization from $\mathrm{CH}_{2} \mathrm{Cl}_{2^{-}}$ hexane gave $42 \mathrm{mg}(66 \%)$ of $17 \mathrm{c}$ as an orange powder: $\mathrm{mp} 102-103{ }^{\circ} \mathrm{C}$; IR $\left(\mathrm{CHCl}_{3}\right) 3450,2980,2940,2820$, $1675,1635,1575,1550,1450,1350 \mathrm{~cm}^{-1} ;{ }^{1} \mathrm{H} \mathrm{NMR}\left(\mathrm{CDCl}_{3}\right) \delta 9.58(\mathrm{~s}, 1 \mathrm{H}), 8.95(\mathrm{~d}, 1 \mathrm{H}, J 4.3 \mathrm{~Hz}), 8.68(\mathrm{~d}, 1 \mathrm{H}, J 8.6$ $\mathrm{Hz}), 8.02(\mathrm{~d}, 1 \mathrm{H}, J 4.3 \mathrm{~Hz}), 7.96(\mathrm{~d}, 1 \mathrm{H}, J 8.6 \mathrm{~Hz}), 7.62(\mathrm{~m}, 1 \mathrm{H}), 7.29(\mathrm{~m}, 1 \mathrm{H}), 3.96(\mathrm{~m}, 1 \mathrm{H}), 3.90(\mathrm{~m}, 2 \mathrm{H}), 2.63-$ $2.46(\mathrm{~m}, 6 \mathrm{H}), 1.34-0.87(\mathrm{~m}, 8 \mathrm{H}) ;{ }^{13} \mathrm{C} N M R\left(\mathrm{CDCl}_{3}\right) \delta 172.6,168.4,156.6,153.5,153.0,151.2,141.2,138.4$, 132.7, 124.9, 124.7, 124.6, 120.5, 118.0, 117.6, 50.0, 46.9, 44.8, 28.0, 11.6; MS m/e $376\left(\mathrm{M}^{+}\right), 290,263,248$, 100, 86 (100\%), 72, 58. Anal. Calcd for $\mathrm{C}_{22} \mathrm{H}_{24} \mathrm{~N}_{4} \mathrm{O}_{2}+0.5 \mathrm{H}_{2} \mathrm{O}: \mathrm{C}, 68.55 ; \mathrm{H}, 6.54 ; \mathrm{N}, 14.54$. Found: $\mathrm{C}, 68.67 ; \mathrm{H}$, $6.41 ; \mathrm{N}, 14.40$.

6-Methylaminoindolo[1,2-b][2,7]naphthyridine-5,12-dione (17d). A solution of $24(0.102 \mathrm{~g}, 0.31 \mathrm{mmol})$ in DMF $(20 \mathrm{~mL})$ was heated at $130{ }^{\circ} \mathrm{C}$ for $24 \mathrm{~h}$. The dark orange red solution was cooled and poured into saturated aqueous $\mathrm{NaHCO}_{3}(50 \mathrm{~mL})$ and extracted with $\mathrm{CH}_{2} \mathrm{Cl}_{2}(3 \times 25 \mathrm{~mL})$. The combined organic phase was washed with $\mathrm{H}_{2} \mathrm{O}(2 \times 50 \mathrm{~mL})$ and brine, dried $\left(\mathrm{Na}_{2} \mathrm{SO}_{4}\right)$, concentrated in vacuo, and dried for $12 \mathrm{~h}$ at $60{ }^{\circ} \mathrm{C}$ in vacuo to give a brick-red solid. Recrystallization from $\mathrm{CH}_{2} \mathrm{Cl}_{2}$-hexane gave $0.073 \mathrm{~g}(86 \%)$ of $17 \mathrm{~d}$ as a dark red powder: $\mathrm{mp} 278-280{ }^{\circ} \mathrm{C}$; IR $\left(\mathrm{CHCl}_{3}\right) 3400,2930,2860,1720,1675,1635,1535,1450,1360,1330 \mathrm{~cm}^{-1} ;{ }^{1} \mathrm{H} \mathrm{NMR}$ $\left(\mathrm{CDCl}_{3}\right) \delta 9.52(\mathrm{~s}, 1 \mathrm{H}), 8.99(\mathrm{~d}, 1 \mathrm{H}, J 4.5 \mathrm{~Hz}), 8.74(\mathrm{~d}, 1 \mathrm{H}, J 8.7 \mathrm{~Hz}), 8.07(\mathrm{~d}, 1 \mathrm{H}, J 4.5 \mathrm{~Hz}), 8.01(\mathrm{~d}, 1 \mathrm{H}, J 8.7 \mathrm{~Hz})$, $7.68(\mathrm{~m}, 1 \mathrm{H}), 7.35$ (m, 1H), 3.70-3.45 (bs, 1H), 3.56 (s, 3H); MS m/e 277 (M+, 100\%), 248, 220, 192, 164, 104, 91, 77. Anal. Calcd for $\mathrm{C}_{16} \mathrm{H}_{11} \mathrm{~N}_{3} \mathrm{O}_{2}+0.25 \mathrm{H}_{2} \mathrm{O}: \mathrm{C}, 68.20 ; \mathrm{H}, 4.11 ; \mathrm{N}, 14.91$. Found: $\mathrm{C}, 68.47 ; \mathrm{H}, 3.97 ; \mathrm{N}, 14.60$.

6-Chloroindolo[1,2-b][2,7]naphthyridine-5,12-dione (27). To a solution of 24 (50 $\mathrm{mg}, 0.15 \mathrm{mmol}$ ) in DMF (5 $\mathrm{mL}$ ) was added $(n-\mathrm{Bu})_{4} \mathrm{NCl}(50 \mathrm{mg}, 0.18 \mathrm{mmol})$. The mixture was stirred at $\mathrm{rt}$ for $12 \mathrm{~h}$ and then poured into $\mathrm{H}_{2} \mathrm{O}$ $\left(25 \mathrm{~mL}\right.$ ). The precipitate was collected by filtration, dried and recrystallized from $\mathrm{CH}_{2} \mathrm{Cl}_{2}$-hexane to yield $29 \mathrm{mg}$ (71\%) of 27 that was identical with an authentic sample by TLC, mp, and MS: mp 220-221 ${ }^{\circ} \mathrm{C}$ (lit. ${ }^{17} \mathrm{mp} 219$ $\left.220^{\circ} \mathrm{C}\right)$; MS m/e $282\left(\mathrm{M}^{+}, 100 \%\right), 254,247,226,219,191,164,114$.

6-Methoxyindolo[1,2-b][2,7]naphthyridine-5,12-dione (28). A solution of 24 (0.0579 $\mathrm{g}, 0.177 \mathrm{mmol})$ in 2:1 THF-MeOH $(10 \mathrm{~mL}$ ) was added dropwise to a solution of NaOMe (from $0.012 \mathrm{~g}, 0.52 \mathrm{mmol}$, of $\mathrm{Na}$ ) in $\mathrm{MeOH}(10$ $\mathrm{mL}$ ) at $0{ }^{\circ} \mathrm{C}$. The mixture was allowed to warm to rt over $2 \mathrm{~h}$ and then poured in $\mathrm{H}_{2} \mathrm{O}(50 \mathrm{~mL})$ and extracted with EtOAc $(3 \times 25 \mathrm{~mL})$. The combined organic phase was washed with $\mathrm{H}_{2} \mathrm{O}(2 \times 50 \mathrm{~mL})$ and brine $(50 \mathrm{~mL})$, then dried $\left(\mathrm{Na}_{2} \mathrm{SO}_{4}\right)$ and concentrated in vacuo to give an orange solid. Recrystallization from $\mathrm{CH}_{2} \mathrm{Cl}_{2}$-hexane gave $0.0321 \mathrm{~g}(65 \%)$ of 28 that was identical with an authentic sample by TLC and mixed melting point: $\mathrm{mp} 212-215$ ${ }^{\circ} \mathrm{C}$ (lit. ${ }^{17} \mathrm{mp} 214-219{ }^{\circ} \mathrm{C}$ ); MS m/e $278\left(\mathrm{M}^{+}\right), 277$ (100\%), 199, 183, 152, 129, 77, 57.

$\mathbf{N}, N^{\prime}$-Octylenebis[6-aminoindolo[1,2-b][2,7]naphthyridine-5,12-dione] (18a). To a solution of 24 (0.50 g, 1.5 $\mathrm{mmol})$ in THF $(25 \mathrm{~mL})$ was added 1,8-diaminooctane $(0.10 \mathrm{~g}, 0.70 \mathrm{mmol})$. The mixture was refluxed for $6 \mathrm{~h}$, then cooled, poured into saturated aqueous sodium bicarbonate solution (100 mL) and extracted with $\mathrm{CH}_{2} \mathrm{Cl}_{2}$ $(3 \times 50 \mathrm{~mL})$. The combined organic phase was washed with saturated aqueous sodium bicarbonate solution $(50 \mathrm{~mL})$, water $(50 \mathrm{~mL})$, and saturated aqueous sodium chloride solution $(50 \mathrm{~mL})$, then dried $\left(\mathrm{Na}_{2} \mathrm{SO}_{4}\right)$ and adsorbed onto silica gel. Elution first with EtOAc, then acetone, then 16:3:1 acetone-MeOH-TEA yielded 0.27 g (48\%) of the di- $\mathrm{HBr}$ salt of $18 \mathrm{a}$ as an orange powder: $\mathrm{mp} 140-145^{\circ} \mathrm{C}(\mathrm{dec})$; IR $\left(\mathrm{CHCl}_{3}\right) 3460,3020,2940,2880$, 1700, 1680, 1630, 1575, 1545, 1455, $1360 \mathrm{~cm}^{-1} ;{ }^{1} \mathrm{H}$ NMR (DMSO- $\left.d_{6}\right) \delta 11.93$ (bs), 9.38-8.52 (m, 6H), 8.03-7.04 $(\mathrm{m}, 8 \mathrm{H}), 3.02(\mathrm{~m}, 4 \mathrm{H}), 1.64-0.80(\mathrm{~m}, 12 \mathrm{H})$; Anal. Calcd for $\mathrm{C}_{38} \mathrm{H}_{32} \mathrm{~N}_{6} \mathrm{O}_{4}+2 \mathrm{HBr}$ : C, 57.16; $\mathrm{H}, 4.29 ; \mathrm{N}, 10.52$. Found: C, 58.69; $\mathrm{H}, 4.67 ; \mathrm{N}, 10.57$.

$\mathbf{N}, N^{\prime}$-(N-Methyl-4-aza-heptylene)bis[6-aminoindolo[1,2-b][2,7]naphthyridine-5,12-dione] (18b). To a solution of $24(0.50 \mathrm{~g}, 1.5 \mathrm{mmol})$ in THF $(25 \mathrm{~mL})$ was added 3,3'-diamino- $N$-methyldipropylamine $(0.10 \mathrm{~g}, 0.70$ $\mathrm{mmol})$. The mixture was refluxed for $6 \mathrm{~h}$, then cooled, poured into saturated aqueous sodium bicarbonate solution $(100 \mathrm{~mL})$ and extracted with $\mathrm{CH}_{2} \mathrm{Cl}_{2}(3 \times 50 \mathrm{~mL})$. The combined organic phase was washed with saturated aqueous sodium bicarbonate solution $(50 \mathrm{~mL})$, water $(50 \mathrm{~mL})$, and saturated aqueous sodium 
chloride solution $(50 \mathrm{~mL})$, then dried $\left(\mathrm{Na}_{2} \mathrm{SO}_{4}\right)$ and adsorbed onto silica gel. Elution first with EtOAc then acetone then 16:3:1 acetone-MeOH-TEA yielded $0.19 \mathrm{~g} \mathrm{(43 \% )}$ of $18 \mathrm{~b}$ as an orange-red powder: $\mathrm{mp} 170-175^{\circ} \mathrm{C}$ (dec); ${ }^{1} \mathrm{H} \mathrm{NMR}\left(\mathrm{CDCl}_{3}\right) \delta 9.41(\mathrm{~s}, 2 \mathrm{H}), 8.85(\mathrm{~m}, 2 \mathrm{H}), 8.44(\mathrm{~d}, 2 \mathrm{H}, J 8.4 \mathrm{~Hz}), 7.85(\mathrm{~d}, 2 \mathrm{H}, J 5.5 \mathrm{~Hz}), 7.52(\mathrm{~d}, 2 \mathrm{H}, J 8.2$ $\mathrm{Hz}), 7.01(\mathrm{~m}, 2 \mathrm{H}), 6.69(\mathrm{~m}, 2 \mathrm{H}), 3.95(\mathrm{~m}, 4 \mathrm{H}), 2.80(\mathrm{~m}, 4 \mathrm{H}), 2.48(\mathrm{~s}, 3 \mathrm{H}), 2.07(\mathrm{~m}, 4 \mathrm{H})$; MS m/e $638\left(\mathrm{M}^{+}\right) . \mathrm{Anal}$. Calcd for $\mathrm{C}_{37} \mathrm{H}_{31} \mathrm{~N}_{7} \mathrm{O}_{4}+2 \mathrm{H}_{2} \mathrm{O}: \mathrm{C}, 65.97 ; \mathrm{H}, 5.23 ; \mathrm{N}, 14.55$. Found: $\mathrm{C}, 66.31 ; \mathrm{H}, 4.90 ; \mathrm{N}, 14.86$.

$\mathbf{N}, \boldsymbol{N}^{\prime}$-(4,9-Dioxa-dodecylene)bis[6-aminoindolo[1,2-b][2,7]naphthyridine-5,12-dione] (18c). To a solution of $24(0.50 \mathrm{~g}, 1.5 \mathrm{mmol})$ in THF $(25 \mathrm{~mL})$ was added 4,9-dioxa-1,12-dodecanediamine $(0.15 \mathrm{~mL}, 0.70 \mathrm{mmol})$. The mixture was refluxed for $6 \mathrm{~h}$, then cooled, poured into saturated aqueous sodium bicarbonate solution (100 $\mathrm{mL}$ ) and extracted with $\mathrm{CH}_{2} \mathrm{Cl}_{2}(3 \times 50 \mathrm{~mL})$. The combined organic phase was washed with saturated aqueous sodium bicarbonate solution $(50 \mathrm{~mL})$, water $(50 \mathrm{~mL})$, and saturated aqueous sodium chloride solution $(50 \mathrm{~mL})$, then dried $\left(\mathrm{Na}_{2} \mathrm{SO}_{4}\right)$ and adsorbed onto silica gel. Elution first with EtOAc, then acetone, then 16:3:1 acetone$\mathrm{MeOH}-\mathrm{TEA}$ yielded $0.22 \mathrm{~g}(45 \%)$ of $18 \mathrm{c}$ as an orange powder: $\mathrm{mp} 165-170{ }^{\circ} \mathrm{C}(\mathrm{dec}) ;{ }^{1} \mathrm{H} \mathrm{NMR}\left(\mathrm{CDCl}_{3}\right) \delta 9.23(\mathrm{~s}$, $2 \mathrm{H}), 8.98(\mathrm{~m}, 2 \mathrm{H}, 8.62(\mathrm{~d}, 2 \mathrm{H}, J 8.0 \mathrm{~Hz}), 8.02(\mathrm{~m}, 2 \mathrm{H}), 7.94(\mathrm{~d}, 2 \mathrm{H}, J 8.1 \mathrm{~Hz}), 7.60(\mathrm{~m}, 2 \mathrm{H}), 7.28(\mathrm{~m}, 2 \mathrm{H}), 3.92(\mathrm{~m}$, $4 \mathrm{H}), 3.63(\mathrm{~m}, 4 \mathrm{H}), 3.54(\mathrm{~m}, 4 \mathrm{H}), 2.07(\mathrm{~m}, 4 \mathrm{H}), 1.78(\mathrm{~m}, 4 \mathrm{H})$; $\mathrm{MS} \mathrm{m} / e 697\left(\mathrm{M}^{+}\right)$. Anal. Calcd for $\mathrm{C}_{40} \mathrm{H}_{36} \mathrm{~N}_{6} \mathrm{O}_{6}+1.75$ $\mathrm{H}_{2} \mathrm{O}: \mathrm{C}, 66.04 ; \mathrm{H}, 5.13 ; \mathrm{N}, 11.55$. Found: C, 66.16; $\mathrm{H}, 5.13 ; \mathrm{N}, 11.83$.

$\mathbf{N}, N^{\prime}$-(Methylenedi-4,1-phenylenebis[6-aminoindolo[1,2-b][2,7]naphthyridine-5,12-dione] (18d). To a solution of $24(0.73 \mathrm{~g}, 2.22 \mathrm{mmol})$ in THF (25 mL) was added 4,4'-methylenedianiline (0.20 g, $1.0 \mathrm{mmol})$. The mixture was refluxed for $6 \mathrm{~h}$, then cooled, poured into saturated aqueous sodium bicarbonate solution (100 $\mathrm{mL}$ ) and extracted with $\mathrm{CH}_{2} \mathrm{Cl}_{2}(3 \times 50 \mathrm{~mL})$. The combined organic phase was washed with saturated aqueous sodium bicarbonate solution $(50 \mathrm{~mL})$, water $(50 \mathrm{~mL})$, and saturated aqueous sodium chloride solution $(50 \mathrm{~mL})$, then dried $\left(\mathrm{Na}_{2} \mathrm{SO}_{4}\right)$ and adsorbed onto silica gel. Elution first with EtOAc, then acetone, then 16:3:1 acetone$\mathrm{MeOH}-\mathrm{TEA}$ yielded $0.16 \mathrm{~g}(23 \%)$ of $\mathbf{1 8 d}$ as a red powder: $\mathrm{mp} 238-239^{\circ} \mathrm{C}(\mathrm{dec})$; IR $\left(\mathrm{CHCl}_{3}\right) 3420,3020,2965$, 1685, 1630, 1615, 1595, 1570, 1550, 1515, 1365, $1210 \mathrm{~cm}^{-1} ;{ }^{1} \mathrm{H}$ NMR $\left(\mathrm{CDCl}_{3}\right) \delta 9.70(\mathrm{~s}, 2 \mathrm{H}), 9.04(\mathrm{~d}, 2 \mathrm{H}, J 5.1$ $\mathrm{Hz}), 8.72(\mathrm{~d}, 2 \mathrm{H}, J 8.5 \mathrm{~Hz}), 8.11(\mathrm{~d}, 2 \mathrm{H}, J 5.1 \mathrm{~Hz}), 7.62(\mathrm{~m}, 2 \mathrm{H}), 7.29(\mathrm{~m}, 4 \mathrm{H}), 7.03(\mathrm{~d}, 4 \mathrm{H}, J 8.4 \mathrm{~Hz}), 6.68(\mathrm{~d}, 4 \mathrm{H}, J$ $8.4 \mathrm{~Hz}$ ), 3.96 (s, 2H), 3.63 (bs, $2 \mathrm{H})$; Anal. Calcd for $\mathrm{C}_{43} \mathrm{H}_{26} \mathrm{~N}_{6} \mathrm{O}_{4}$ : C, 74.78; $\mathrm{H}, 3.79 ; \mathrm{N}, 12.17$. Found: $\mathrm{C}, 75.02 ; \mathrm{H}$, $4.81 ; \mathrm{N}, 12.04$.

Procedure for determination of $\Delta \mathrm{T}_{\mathrm{m}}$ values. The thermal denaturation studies were done by the method of Cory $^{34}$ on a Varian 2290 UV-visible spectrophotometer with a heating rate of $18{ }^{\circ} \mathrm{C} / \mathrm{h}$. The five cuvettes were on a 2 min cycle time with a $5 \mathrm{sec}$ dwell time. $\Delta \mathrm{T}_{\mathrm{m}}$ values were calculated from the printout using the difference between the compound $T_{m}$ and the DNA. The calf thymus DNA had a $T_{m}$ of $56.8^{\circ} \mathrm{C}$.

\section{Acknowledgements}

We thank Dartmouth College for support of this work and Wendy Berryman for technical assistance.

\section{References}

1. Polyakov, N.; Leshina, T.; Fedenok, L.; Slepneva, I.; Kirilyuk, I.; Furso, J.; Olchawa, M.; Sarna, T.; Elas, M.; Bilkis, I.; Weiner, L. Antioxidants Redox Signal. 2018, 28, 1394.

https://doi.org/10.1089/ars.2017.7406

2. Tišler, M. Adv. Heterocycl. Chem. 1989, 45, 37.

https://doi.org/10.1016/S0065-2725(08)60329-3 
3. Franck, R. W.; Tomasz, M. Wilman, D. E. V., Ed. Blackie: London, 1990. Chemistry of Antitumour Agents; Chap. 15, The Chemistry of Mitomycins; p379.

4. Delgado, J. L.; Hsieh, C-M.; Chan, N-L.; Hiasa, H. Biochem. J. 2018, 475, 373. https://doi.org/10.1042/BCJ20160583

5. Remers, W. A.; Cragg, G. M.; Kingston, D. G. I.; Newman, D. J., Eds. CRC Press: Boca Raton, FL, 2012. Anticancer Agents from Natural Products; The Mitomycins; $2^{\text {nd }}$ Ed. p623.

6. Han, I.; Russell, D. J.; Kohn, H. J. Org. Chem. 1992, 57, 1799. https://doi.org/10.1021/jo00032a037

7. Martelli, S.; Dzieduszycka, M.; Stefanska, B.; Bontemps-Gracz, M.; Borowski, E. J. Med. Chem. 1988, 31, 1956. https://doi.org/10.1021/jm00118a015

8. Enache, M.; Toader, A. M.; Enache, M. I. Molecules 2016, 21, 1356. https://doi.org/10.3390/molecules21101356

9. Green, A. K.; Corty, R. W.; Wood, W. A.; Meeneghan, M.; Reeder-Hayes, K. E.; Basch, E.; Milowsky, M. I.; Dusetzina, S. B. The Oncologist 2015, 20, 516.

https://doi.org/10.1634/theoncologist.2014-0432

10. Krapcho, A. P. Curr. Org. Chem. 2015, 19, 886. https://doi.org/10.2174/1385272819666150119224450

11. Huebel, K. Exp. Opin. Pharmacother. 2018, 19, 1829. https://doi.org/10.1080/14656566.2018.1528232.

12. Minotti, G.; Han, H.; Cattan, V.; Egorov, A.; Bertoni, F. Exp. Rev. Hematol. 2018, 11, 587. https://doi.org/10.1080/17474086.2018.1476848

13. Konda, S. K.; Kelso, C.; Medan, J.; Sleebs, B. E.; Phillips, D. R.; Cutts, S. M.; Collins, J. G. Org. Biomol. Chem. 2016, 14, 10217. https://doi.org/10.1039/C6OB02100J

14. Konda, S. K.; Kelso, C.; Pumuye, P. P.; Medan, J.; Sleebs, B. E.; Cutts, S. M.; Phillips, D. R.; Collins, J. G. Org. Biomol. Chem. 2016, 14, 4728. https://doi.org/10.1039/C6OB00561F

15. Saulnier, M. G.; Gribble, G. W. J. Org. Chem. 1982, 47, 2810. https://doi.org/10.1021/jo00135a034

16. Saulnier, M. G.; Gribble, G. W. Tetrahedron Lett. 1983, 24, 3831. https://doi.org/10.1016/S0040-4039(00)94287-4

17. Ketcha, D. M.; Gribble, G. W. J. Org. Chem. 1985, 50, 5451. https://doi.org/10.1021/jo00350a001

18. Obaza-Nutaitis, J. A.; Gribble, G. W. J. Nat. Prod. 1986, 49, 449. https://doi.org/10.1021/np50045a011

19. Gribble, G. W.; Saulnier, M. G.; Obaza-Nutaitis, J. A.; Ketcha, D. M. J. Org. Chem. 1992, 57, 5891. https://doi.org/10.1021/jo00048a022

20. Gruver, E. J.; Onyango, E. O.; Gribble, G. W. Arkivoc. 2018, iii, 144. https://doi.org/10.24820/ark.5550190.p010.414

21. Gribble, G. W.; Fletcher, G. L.; Ketcha, D. M.; Rajopadhye, M. J. Org. Chem. 1989, 54, 3264. https://doi.org/10.1021/jo00275a008

22. Fraser, H. L.; Gribble, G. W. Can. J. Chem. 2001, 79, 1515. https://doi.org/10.1139/v01-127 
23. Nishiyama, T.; Hatae, N.; Mizutani, M.; Yoshimura, T.; Kitamura, T.; Miyano, M.; Fujii, M.; Satsuki, N.; Ishikura, M.; Hibino, S.; Choshi, T. Eur. J. Med. Chem. 2017, 136, 1.

https://doi.org/10.1016/i.ejmech.2017.04.071

24. Bernardo, P. H.; Chai, C. L. L.; Heath, G. A.; Mahon, P. J.; Smith, G. D.; Waring, P.; Wilkes, B. A. J. Med. Chem. 2004, 47, 4958.

https://doi.org/10.1021/jm0496250

25. Parvatkar, P. T. Curr. Org. Chem. 2016, 20, 839.

https://doi.org/10.2174/1385272819666150803235103

26. Davis, D. A.; Gribble, G. W. Heterocycles 1992, 34, 1613.

https://doi.org/10.3987/COM-92-6087

27. Saxton, J. E. J. Chem. Soc. 1952, 3592.

https://doi.org/10.1039/jr9520003592

28. Sundberg, R. J. Academic: New York, 1970. The Chemistry of Indoles, p34.

29. Ashcroft, W. R.; Dalton, L.; Beal, M. G.; Humphrey, G. L.; Joule, J. A. J. Chem. Soc., Perkin Trans. 1. 1983, 2409.

https://doi.org/10.1039/P19830002409

30. Bair, K. W.; Andrews, C. W.; Tuttle, R. L.; Knick, V. C.; Cory. M.; McKee, D. D. J. Med. Chem. 1991, 34, 1983. https://doi.org/10.1021/im00111a010

31. Lord, W. M.; Peters, A. T. J. Chem. Soc. (C). 1968, 783.

https://doi.org/10.1039/j39680000783

32. Gribble, G. W.; Mosher, M. D.; Jaycox, G. D.; Cory, M.; Fairley, T. A. Heterocycles 2014, 88, 535.

https://doi.org/10.3987/COM-13-S(S)77

33. Pohland, A. E.; Benson, W. R. Chem. Rev. 1966, 66, 161.

https://doi.org/10.1021/cr60240a003

34. Cory, M.; McKee, D. D.; Kagan, J.; Henry, D. W.; Miller, J. A. J. Amer. Chem. Soc. 1985, 107, 2528.

https://doi.org/10.1021/ja00294a054

35. Ross, W. E. Biochem. Pharmacol. 1985, 34, 4191.

https://doi.org/10.1016/0006-2952(85)90273-4

36. Conway, S. C.; Gribble, G. W. Heterocycles 1990, 30, 627.

https://doi.org/10.3987/COM-89-S79 